\title{
Can the parasitic fauna on Nile tilapias be affected by different production systems?
}

\author{
MAURÍCIO L. MARTINS ${ }^{1}$, TATIANA M.P. AZEVEDO ${ }^{1}$, LUCIANA GHIRALDELLI ${ }^{1}$ and NEUZA BERNARDI ${ }^{2}$ \\ ${ }^{1}$ Laboratório AQUOS, Sanidade de Organismos Aquáticos, Departamento de Aquicultura, CCA \\ Universidade Federal de Santa Catarina (UFSC), Rod. Admar Gonzaga, 1346, 88040-900 Florianópolis, SC, Brasil \\ ${ }^{2}$ Departmento de Engenharia Química, UFSC, Rod. SC 404, Trindade, 88040-900 Florianópolis, SC, Brasil
}

Manuscript received on July 2, 2008; accepted for publication on June 26, 2009

\begin{abstract}
This study compared the parasitic fauna on Nile tilapias kept with swine dejects and tilapia from fee fishing fed commercial ration. A total of 360 fish were analyzed from August 2003 to July 2004 in a facility situated in Nova Trento, Santa Catarina, Brazil. No significant difference was observed in both systems. The parasite fauna in both systems were slightly similar, with the presence of the following parasites: Trichodina magna and T. compacta (Ciliophora); Cichlidogyrus sclerosus and Cichlidogyrus sp. (Monogenoidea); and Lamproglena sp. (Lernaeidae). Parasitological analyzes did not differ among fishes kept with swine dejects and in fee fishing with commercial diet $(\mathrm{P}>0.05)$. The total prevalence of trichodinids in the gills of fish kept with swine dejects was $1.7 \%$ as compared to the one kept in fee fishing with commercial diet $(0.6 \%)$. The Monogenoidea prevalence and mean intensity in the gills and body of fish from fee fishing was $16.5 \%$ and 2.6 , and compared to other system was $13.2 \%$ and 0.8 , respectively. This study showed that low stocking density and low water temperature in that region were responsible for the maintenance of good health and lower parasitism rate.
\end{abstract}

Key words: Oreochromis niloticus, fee fishing, swine dejects, Monogenoidea, Trichodina, prevalence.

\section{INTRODUCTION}

In 1990, an economy based on the integrated production of fish and swine culture has been developed, in which today, the most raised fish species are tilapia (Oreochromis niloticus) and carp (Cyprinus carpio) (Souza et al. 2003).

During the last years, there has been a significant increase in the facilities that practice the fee fishing system (sportive fish culture). The intensive system of fish maintenance is characterized by an increasing in stocking density, which leads to problems related to inappropriate handling, feeding, infectious and parasitic diseases (Martins et al. 2002, 2008). These problems are considered the main causes of economical losses in the

Correspondence to: Dr. Maurício Laterça Martins

E-mail: mlaterca@cca.ufsc.br industrial and sportive fish culture (Tavares-Dias et al. 2001a).

In Brazil, Békési (1992) pointed out the first cases of parasitism in raised fishes from the Northeast; Malta et al. (2001) and Varella et al. (2003) from the Amazon; Martins et al. (2002) from the Southeast; Vargas et al. (2000), Fortes et al. (1998), and Ghiraldelli et al. (2006a) from the South Brazil.

According to Martins et al. (2002), the main fish parasites recorded in the Southeast Brazil are: Piscinoodinium pillulare (Dinoflagellida) (Schäperclaus, 1954 redescription by Lom, 1981); trichodinids, Ichthyophthirius multifiliis (Ciliophora) Fouquet, 1876; Henneguya piaractus (Myxozoa) Martins and Souza 1997; Anacanthorus penilabiatus (Monogenoidea) Boeger, Husak and Martins 1995; Lernaea cyprinacea (Cope- 
poda) Linnaeus, 1758; and, more recently, Lamprogle$n a$ von Nordmann, 1832 as the second important copepod parasite in freshwater fish (Piasecki et al. 2004). In the South Brazil, Ghiraldelli et al. (2006a) and Martins and Ghiraldelli (2008) identified trichodinids and Monogenoidea as the most dominant fish-cultured parasites.

Nile tilapias are widely reared in the tropics, representing the second species reared all over the world (Cavichiolo et al. 2002). In the Southeast region, the tilapia showed an incidence of $40 \%$ incidence of diseases (Martins et al. 2002) that, in several times, influenced its health and haematological parameters (Ghiraldelli et al. 2006b).

There are no epidemiological data concerning ectoparasites from reared tilapia in the South Brazil. To date, comparative field studies among parasitic fauna on tilapia kept in an environment that receives swine dejects and commercial ration are not registered around the world. Thus, this study was carried out for 12 months to compare ectoparasites from tilapia kept with swine dejects and in fee fishing fed commercial diet in the South Brazil.

\section{MATERIALS AND METHODS}

From August 2003 to July 2004, 360 Nile tilapias were catched by net in Nova Trento town $\left(27^{\circ} 17^{\prime} 09^{\prime \prime} \mathrm{S}\right.$, $\left.48^{\circ} 55^{\prime} 47^{\prime \prime} \mathrm{W}\right)$, S.C., Brazil. The animals kept with swine dejects $(n=180)$ presented $26.8 \pm 1.1 \mathrm{~cm}$ of total length and $385.0 \pm 37.5 \mathrm{~g}$ of mean weight, at a stocking density of $3 \mathrm{fish} / \mathrm{m}^{2}$. The others, from fee fishing $(\mathrm{n}=180)$, measured $28.5 \pm 2.0 \mathrm{~cm}$ and weighted $456 \pm 86.8 \mathrm{~g}$, at a stocking density of $4 \mathrm{fish} / \mathrm{m}^{2}$. During the sampling days, water temperature, dissolved oxygen, $\mathrm{pH}$, alkalinity and transparency were all obtained. A $250 \mathrm{~mL}$ water sample from the ponds was frozen for ammonia analyses according to Koroleff (1976).

After sacrifice and biometrical evaluation being sacrificed and evaluated biometrically for parasitological examination (Ethic Committee no. 23080.017229/ 2004-78/UFSC), according to Ghiraldelli et al. (2006a) and Martins and Ghiraldelli (2008). Prevalence and mean intensity were calculated by Bush et al. (1997). These results were analyzed by the Spearman's test with a 0.05 significance rate, and the ANOVA F statistic for a variance analysis, whereas the average comparison of parasite number, in each month and between the both systems, was performed by Tukey test (Mendes 1999).

\section{RESULTS}

The water quality measured during the whole period did not show a significant difference $(P>0.05)$ when both the pond that received swine dejects and fee fishing were compared (Tables I and II). The mean values of water temperature were the lowest in August 2003 and in May-July 2004; the highest ones were observed in November-December 2003 and in January-February 2004. Although the dissolved oxygen concentration in fee fishing was elevated from August to October 2003, no difference was observed in relation to the swine dejects system. As shown in Table I, pH and alkalinity did not differ in both systems. Although the fish were kept with swine dejects, the ammonia concentration was kept in tolerable levels. Interestingly, no difference was observed between the systems. Swine dejects supplementation in the water was responsible for the decrease in water transparency, as observed in the majority of the analyzed months. No significant difference among parasitological data in both systems was observed.

From 360 examined animals, 66 (18.3\%) were parasitized during the whole period, 20 (5.5\%) with Trichodina magna Van As and Basson, 1989 and T. compacta (Protozoa: Ciliophora) Van As and Basson, 1989; 64 (17.8\%) with Cichlydogyrus Paperna, 1960 and Cichlydogyrus sclerosus (Monogenoidea: Dactylogyridae) Paperna and Thurston, 1969 on body and gills; and 4 (1.1\%) with Lamproglena (Crustacea: Lernaeidae) von Nordmann, 1832 in the gill arches.

The total prevalence rate of trichodinids was higher in fish's gills from the pond with swine dejects than those of fee fishing (Tables I and II). In this case, this protozoan was present only in August and September 2003. When analyzing the averages of the whole period, Monogenoidea prevalence in the gills was higher $(16.5 \%)$ in fish from fee fishing than those kept with swine dejects (13.2\%). Although without significant difference $(\mathrm{P}>0.05)$, fishes from fee fishing were more parasitized by Monogenoidea than those kept with swine dejects. 
TABLE I

Water quality and parasitic characteristics of Nile tilapias $(n=180)$ kept in fee fishing system from Valley of Tijucas River, Santa Catarina, Brazil. T: temperature; $\mathrm{O}_{2}$ : dissolved oxygen; $\mathrm{NH}_{3}$ : ammonia; Alkal: alkalinity; Tran: transparency; P: prevalence; MI: mean intensity; G: gill; B: body surface.

\begin{tabular}{|c|c|c|c|c|c|c|c|c|c|c|c|c|c|c|}
\hline \multirow{3}{*}{ Months } & \multicolumn{6}{|c|}{ Water quality } & \multicolumn{4}{|c|}{ Monogenoidea } & \multicolumn{2}{|c|}{ Trichodinid } & \multicolumn{2}{|c|}{ Lamproglena } \\
\hline & $\begin{array}{c}\mathrm{T} \\
{ }^{\circ} \mathrm{C}\end{array}$ & $\begin{array}{c}\mathrm{O}_{2} \\
\mathrm{mg} / \mathrm{L}\end{array}$ & $\mathrm{pH}$ & $\begin{array}{l}\mathrm{NH}_{3} \\
\mathrm{mg} / \mathrm{L}\end{array}$ & $\begin{array}{l}\text { Alkal } \\
\text { mg/L }\end{array}$ & $\begin{array}{l}\text { Tran } \\
\mathrm{cm}\end{array}$ & $\begin{array}{c}\mathrm{P} \\
(\%)\end{array}$ & & $\mathrm{MI}$ & & $\begin{array}{c}\mathrm{P} \\
(\%)\end{array}$ & & $\begin{array}{c}\mathrm{P} \\
(\%)\end{array}$ & MI \\
\hline & & & & & & & G & $\mathrm{B}$ & $\mathrm{G}$ & B & $\mathrm{G}$ & B & $\mathrm{G}$ & B \\
\hline Aug/03 & 19.3 & 9.3 & 7.1 & 0.500 & 20 & 25 & 60 & 13 & 14.6 & 0 & 7 & 13 & 20 & 1.4 \\
\hline $\mathrm{Sep} / 03$ & 19.0 & 8.3 & 7.0 & 0 & 25 & 22 & 46 & 0 & 6.3 & 0 & 0 & 13 & 0 & 0 \\
\hline Oct/03 & 22.5 & 8.5 & 6.5 & 0.108 & 30 & 14 & 0 & 26 & 0 & 3.2 & 0 & 0 & 0 & 0 \\
\hline Nov/03 & 24.4 & 4.0 & 6.5 & 0.103 & 30 & 18 & 26 & 0 & 1.5 & 0 & 0 & 0 & 0 & 0 \\
\hline Dec/03 & 28.1 & 5.8 & 6.5 & 0 & 30 & 17 & 6 & 0 & 1.0 & 0 & 0 & 0 & 0 & 0 \\
\hline $\mathrm{Jan} / 04$ & 26.3 & 6.4 & 5.1 & 0.032 & 30 & 15 & 20 & 0 & 2.0 & 0 & 0 & 0 & 0 & 0 \\
\hline Feb/04 & 25.4 & 7.8 & 7.4 & 0.135 & 30 & 10 & 0 & 0 & 0 & 0 & 0 & 0 & 0 & 0 \\
\hline Mar/04 & 32.0 & 6.5 & 5.6 & 0.136 & 20 & 22 & 0 & 0 & 0 & 0 & 0 & 0 & 0 & 0 \\
\hline Apr/04 & 24.0 & 3.8 & 6.0 & 0.313 & 50 & 20 & 20 & 0 & 2.0 & 0 & 0 & 0 & 0 & 0 \\
\hline May/04 & 19.2 & 3.5 & 5.1 & 0.043 & 40 & 20 & 26 & 0 & 4.0 & 0 & 0 & 0 & 0 & 0 \\
\hline Jun/04 & 17.3 & 3.8 & 6.2 & 0.160 & 30 & 10 & 0 & 0 & 0 & 0 & 0 & 0 & 0 & 0 \\
\hline Jul/04 & 18.3 & 4.3 & 6.5 & 0.131 & 30 & 10 & 0 & 0 & 0 & 0 & 0 & 0 & 0 & 0 \\
\hline Mean & 23.0 & 6.0 & 6.3 & 0.116 & 30 & 17 & 16.5 & 3 & 2.6 & 0.3 & 0.6 & 2.2 & 1.7 & 0.1 \\
\hline
\end{tabular}

TABLE II

Water quality and parasitic characteristics of Nile tilapias $(n=180)$ kept with swine dejects from Valley of Tijucas River, Santa Catarina, Brazil. T: temperature; $\mathrm{O}_{2}$ : dissolved oxygen; $\mathrm{NH}_{3}$ : ammonia; Alkal: alkalinity; Tran: transparency; P: prevalence; MI: mean intensity; G: gills; B: body surface.

\begin{tabular}{|c|c|c|c|c|c|c|c|c|c|c|c|c|c|c|}
\hline \multirow{3}{*}{ Months } & \multicolumn{6}{|c|}{ Water quality } & \multicolumn{4}{|c|}{ Monogenoidea } & \multicolumn{2}{|c|}{ Trichodinid } & \multicolumn{2}{|c|}{ Lamproglena } \\
\hline & $\begin{array}{c}\mathrm{T} \\
{ }^{\circ} \mathrm{C}\end{array}$ & $\begin{array}{c}\mathrm{O}_{2} \\
\mathrm{mg} / \mathrm{L}\end{array}$ & $\mathrm{pH}$ & $\begin{array}{l}\mathrm{NH}_{3} \\
\mathrm{mg} / \mathrm{L}\end{array}$ & $\begin{array}{l}\text { Alkal } \\
\text { mg/L }\end{array}$ & $\begin{array}{c}\text { Tran } \\
\mathrm{cm}\end{array}$ & $\begin{array}{c}\mathrm{P} \\
(\%)\end{array}$ & & MI & & $\begin{array}{c}\mathrm{P} \\
(\%)\end{array}$ & & $\begin{array}{c}\mathrm{P} \\
(\%) \\
\end{array}$ & MI \\
\hline & & & & & & & $\mathrm{G}$ & B & $\mathrm{G}$ & B & $\mathrm{G}$ & B & G & B \\
\hline Aug/03 & 18.2 & 5.7 & 7.0 & 0.500 & 40 & 4 & 66 & 0 & 3.3 & 0 & 13 & 0 & 0 & 0 \\
\hline $\mathrm{Sep} / 03$ & 20.0 & 6.8 & 6.0 & 0 & 20 & 7 & 80 & 0 & 3.3 & 0 & 7 & 7 & 6.6 & 2 \\
\hline Oct/03 & 22.7 & 5.8 & 6.5 & 0.098 & 20 & 16 & 0 & 0 & 0 & 0 & 0 & 0 & 0 & 0 \\
\hline Nov/03 & 25.3 & 3.8 & 6.0 & 0.107 & 30 & 12 & 6 & 0 & 1.0 & 0 & 0 & 0 & 0 & 0 \\
\hline $\mathrm{Dec} / 03$ & 28.8 & 3.8 & 6.5 & 0.072 & 30 & 22 & 0 & 6 & 1.0 & 0 & 0 & 0 & 0 & 0 \\
\hline Jan/04 & 26.9 & 4.1 & 4.8 & 0.048 & 30 & 18 & 13 & 0 & 1.5 & 0 & 0 & 0 & 0 & 0 \\
\hline Feb/04 & 25.1 & 5.9 & 7.8 & 0.194 & 30 & 18 & 0 & 0 & 0 & 0 & 0 & 0 & 0 & 0 \\
\hline Mar/04 & 27.6 & 5.5 & 5.4 & 0.151 & 25 & 9 & 0 & 0 & 0 & 0 & 0 & 0 & 0 & 0 \\
\hline Apr/04 & 24.5 & 3.1 & 5.5 & 0.073 & 80 & 12 & 0 & 0 & 0 & 0 & 0 & 0 & 0 & 0 \\
\hline May/04 & 19.0 & 3.1 & 5.1 & 0.199 & 30 & 10 & 0 & 0 & 0 & 0 & 0 & 0 & 0 & 0 \\
\hline Jun/04 & 18.0 & 3.2 & 6.3 & 0.348 & 30 & 10 & 0 & 0 & 0 & 0 & 0 & 0 & 0 & 0 \\
\hline Jul/04 & 18.7 & 3.8 & 6.7 & 0.143 & 30 & 10 & 0 & 0 & 0 & 0 & 0 & 0 & 0 & 0 \\
\hline Mean & 22.9 & 4.5 & 6.1 & 0.143 & 33 & 12 & 13.2 & 0.5 & 0.8 & 0 & 1.7 & 0.6 & 0.5 & 0.2 \\
\hline
\end{tabular}


Monogenoidea prevalence and mean intensity were higher in August and September 2003 when compared to the other months, not only in fishes from fee fishing, but also in those from the pond with swine dejects. It is not possible to confirm whether there was a relationship between parasite number and prevalence with temperature. But, it was observed that the copepod Lamproglena sp. was present in fishes from feefishing, in August 2003 (prevalence $20 \%$ and mean intensity 1.4) and September 2003 (prevalence 6.6\% and mean intensity 2).

\section{DISCUSSION}

The rapid development of aquaculture in Brazil has caused low water quality, handling stress, and inadequate source of feeding, which has led to an increased number of parasites. Other economic losses have occurred as a result of imbalance in the host/parasite/environment system (Ghiraldelli et al. 2006b). The Nile tilapia is one of the most raised fish in the South Brazil. Only in the last decade parasitological studies from raised fish have been reported (Békési 1992, TavaresDias et al. 2001a, b, Ghiraldelli et al. 2006a). The presence of trichodinids associated to low water quality or fish mortality was reported in São Paulo (Tavares-Dias et al. 2001a, Martins et al. 2002), Paraná (Vargas et al. 2000) and Ceará States and in the Amazon region (Békési 1992, Andrade et al. 2001).

Trichodinids are considered as commensals, which are found on the skin surface and gills, feeding on mucus, cells, and bacteria. They include an important group of ectoparasites in freshwater fish since their presence is directly related to water quality. Experimental infections with Trichodina truttae Müeller, 1937 revealed fish mortality as related by Urawa (1992), and with Trichodina jadranica Raabe, 1958 caused disease in eel from recirculating aquaculture (Mellergaard and Dalsgaard 1987). Mixed infections, which were observed in this study, corroborated the findings of Barker et al. (2002) who reported Trichodina murmanica Polyanski, 1955 and Gyrodactylus pleuronecti Cone, 1981 in flounder.

In the present study, the number of trichodinids coincided with the category 1 (1-10 parasites) of Madsen et al. (2000). Their prevalence in August and September 2003 corroborated the observations of Tavares-Dias et al. (2001a) and Martins et al. (2002) in tilapias. Although seasonality in the trichodinid's prevalence was not observed, the highest values were recorded in August and September 2003 for both systems. It can also be mentioned the lack of trichodinids' pathogenicity in this study, as confirmed by Madsen et al. (2000) observations. However, we concluded that the pathogenicity was directly related to the number of parasites on fish (category 1 of Madsen et al. 2000) and is associated to water quality as reported by Afif et al. (2000).

Several species of the genus Oreochromis have been introduced in Africa and America with Monogenoidea (Kritsky and Thatcher 1974). In this work, Monogenoidea total prevalence was lower than the one observed by Flores-Crespo et al. (1992). In this work, despite the highest mean intensity in August and September 2003, symptoms of disease were not observed, which was different of what was found by Kaneko et al. (1988). Buchmann et al. (1995) emphasized the importance of Monogenoidea in Danish rainbow trout culture, since some of them occur in a specific season and the others present high values during the whole year. In the present study, tilapias showed low infestation by Monogenoidea and trichodinids, corroborating the results obtained by Tavares-Dias et al. (2001b). The total prevalence rate of Monogenoidea in fishes from fee fishing and pond that received swine dejects was similar to that found by Tavares-Dias et al. (2001b), which was also in fee fishing situated in the Southeast Brazil. But, it must be emphasized that the prevalence was higher (46-80\%) in August and September 2003 than that one mentioned on the same fish from the Southeast Brazil. Monogenoidea's mean intensity showed the highest values in the fall and spring, while Tavares-Dias et al. (2001b) reported them in the spring and summer in P. mesopotamicus and L. macrocephalus.

The genus Lamproglena is the most primitive group of Lernaeidae (Thomas and Hameed 1984) and the second major gill freshwater parasite cyclopoid (Piasecki et al. 2004). It occurs in Africa (Marx and Avenant-Oldewage 1996), Asia (Kumari et al. 1989), Turkey (Saglam 1998), Europe (Galli et al. 2001), and Brazil (Martins et al. 2002). In contrast of the season- 
ality of Lamproglena minuta Capart 1943 in Puntius binotatus Valenciennes 1842 and its relation with the fish size observed by Leong (1986), in this study, there was no relation between the parasitism and the sampling months.

According to Duëllou and Erlwanger (1994), Tilapia rendalli Boulenger, 1897 is one of the most preferred hosts for Lamproglena monodi Capart, 1944, with high values of prevalence and parasite number when compared to the findings of the present study.

Similar prevalence and mean intensity of Lamproglena were reported in Chondrostoma regium Heckel, 1843 parasitized by Lamproglena pulchella von Nordmann 1832 (Saglam 1998). Lamproglena clariae (Fryer 1956) is endemic in Africa, and Marx and Avenant-Oldewage (1996) assigned the infestation to unpolluted sites. It can also be added that in the majority of the cases, Lamproglena occurs in intensities from 1 to 5 parasites. Moreover, L. monodi has been found in O. niloticus, reared in the Philippines, at the mean intensity of 1 to 3.5 parasites per fish (Yambot and Lopez 1996), which was similar to this trial. In Brazil, the lack of data in raised fish during the last 15 years does not allow any conclusion on its introduction. The low intensity of parasitism may be responsible for unknown effects on survival and growth of the hosts. Six percent prevalence of Lamproglena in tilapia reared in ponds and cages in São Paulo, Brazil (Martins et al. 2002) were not directly associated to mortality.

Except for the lowest dissolved oxygen and the highest ammonia concentration in the pond that received swine dejects, the analyses of water quality was similar in both systems. It must be noted that the presence of swine dejects was probably responsible for the worst parameters. Although the fee fishing system had presented a higher fish density than pond with swine dejects, oxygen and ammonia did not increase. This is especially true when analyzing the results obtained by Dhawan and Kaur (2002) that concluded any effects of swine dejects in the water quality. In this study, a great amount of algae was observed in the surface of the pond that received swine dejects. Low temperature was probably the main factor that avoided low water quality in that system.
In this context, Skinner (1982) observed a high infection rate by Monogenoidea in fishs from environments with high amounts of ammonia. This trial could not prove this fact probably because ammonia concentration was not that high. On the contrary, high prevalence rates of trichodinids were associated with water temperature in fishes from India (Singhal et al. 1986) and from Finland lakes (Halmetoja et al. 1992). This study was not able to establish a relationship between water quality and parasites. Considering the fee fishing system, high stocking density caused a slight increase in the prevalence and number of Monogenoidea. This result is in accordance to Koskivaara et al. (1991) findings in roaches from eutrophic and polluted lakes in Finland. Moreover, the mean intensity of this work was excessively higher than that related to roaches. The effects of water quality on the parasite community were also studied in polluted and unpolluted Lake in Central Finland (Bagge and Valtonen 1996). Although direct relationship with our results was not possible, it can be inferred that water quality may affect the parasite community. To date, Galli et al. (2001) have observed the negative effects of the pollution on the infection with L. pulchella in fishes from lakes in Italy. In intensive fish farming, this condition must be considered by the fact that the low water flow and high organic matter contents constitute better substrates for parasite reproduction.

Parasitologists have been closely observed the mechanisms involved in host response, which depend on interactions among host/parasite/environment and, in several times, on specific substances (Buchmann and Lindestrom 2002). Some of the factors that are responsible for the decrease of fish resistance are: surrounding temperature, water quality, stress level, quality and quantity of feeding, age, and natural immunity depending on fish species. Finally, the severity of disease depends on the parasite capacity of infection and environmental quality in which fishes are kept. Data collected here indicate the difference in the parasite number harbored by tilapias reared in the Brazil (Tavares-Dias et al. 2001a, b). In the Southeast Brazil, 20-30 ${ }^{\circ} \mathrm{C}$ of water temperature might improve parasite reproduction, as well as the release of toxic substances from the bottom of ponds. 


\section{ACKNOWLEDGMENTS}

The authors thank Dr. Walter A. Boeger and Rogério T. Viana (Departamento de Zoologia, Universidade Federal do Paraná, PR, Brasil) who kindly identified Monogenoidea and "Pesca e Lazer Tridapalli" facility for fish donation. This study was financially supported by "Conselho Nacional de Desenvolvimento Científico e Tecnológico/CNPq" - 300281/04-8, 470100/04-4).

\section{RESUMO}

Este estudo comparou a fauna parasitária de tilápia do Nilo mantida em consorciação com suínos e alimentada com ração comercial mantida em pesque-pague. Um total de 360 peixes foi analisado, entre agosto de 2003 e julho de 2004, em uma propriedade de Nova Trento, Santa Catarina, Brasil. Não houve diferença significativa entre os dois sistemas de cultivo. A fauna parasitária em ambos foi ligeiramente semelhante com a presença de Trichodina magna e T. compacta (Ciliophora); Cichlidogyrus sclerosus e Cichlidogyrus sp. (Monogenoidea) e Lamproglena sp. (Lernaeidae). A análise parasitológica não mostrou diferença entre os peixes dos dois sistemas. A prevalência total de tricodinídeos nas brânquias dos peixes mantidos com dejetos de suínos foi de 1,7\% quando comparada com os do pesque-pague de $0,6 \%$. A taxa de prevalência e a intensidade média de Monogenoidea nas brânquias dos peixes do pesque-pague foi de $16,5 \%$ e 2,6 , respectivamente comparada com os mantidos com suínos de $13,2 \%$ e 0,8 , respectivamente. Este estudo demonstrou que a baixa densidade de estocagem de peixes nesta propriedade e a baixa temperatura na região colaboraram para que a saúde dos animais fosse mantida e o nível de parasitismo baixo.

Palavras-chave: Oreochromis niloticus, pesque-pague, dejetos de suínos, Monogenoidea, Trichodina, prevalência.

\section{REFERENCES}

Afif SH, Thobiati AL and HazaA MS. 2000. Parasitic gill lesions in Nile tilápia Oreochromis niloticus from fish farms in Saudi Arabia. Assiut Vet Med J 42(84): 183-194.

Andrade SMS, Malta JCO And FERraz E. 2001. Fauna parasitológica de alevinos de matrinxã Brycon cephalus (Günther, 1869) coletados nos rios Negro e Solimões, na Amazônia Central. Acta Amazonica 31: 263-273.

BAgGe AM AND VALTONEN ET. 1996. Experimental study on the influence of paper and pulp mill effluent on the gill parasite communities of roach (Rutilus rutilus). Parasitology 112: 499-508.

BARKer DE, CONE DK AND Burt MDB. 2002. Trichodina murmanica (Ciliophora) and Gyrodactylus pleuronecti (Monogenea) parasitizing hatchery-reared winter flounder, Pleuronectes americanus (Walbaum): effects on host growth and assessment of parasite interaction. J Fish Dis 25: $81-89$.

BÉKÉSI L. 1992. Evaluation of data on ichthyopathological analyses in the Brazilian Northeast. Ci e Cult 44: 400403.

BUCHMANN K AND LindESTROM T. 2002. Interactions between monogenean parasites and their fish hosts. Int $\mathrm{J}$ Parasitol 32: 309-319.

Buchmann K, Uldal A And Lyholt HCK. 1995. Parasite infections in Danish trout farms. Acta Vet Scandinavica 36: 283-298.

Bush AO, Lafferty KD, Lotz JM and Shostak W. 1997. Parasitology meets ecology on its own terms: Margolis et al. revisited. J Parasitol 83: 575-583.

Cavichiolo F, VArgas L, Ribeiro RP, Moreira HLM AND LEONARDO JM. 2002. Níveis de suplementação de vitamina $\mathrm{C}$ na ração sobre a ocorrência de ectoparasitas, sobrevivência e biomassa em alevinos de tilápia do Nilo (Oreochromis niloticus L.). Acta Scientiarum 24: 957964.

DhaWAn A AND KaUR S. 2002. Effect of swine dejects on water quality and polyculture of carp species during winter and summer. Aquac Int 10: 297-307.

DOUËLlOU L AND ERLWANGER KH. 1994. Crustacean parasites of fishes in Lake Kariba, Zimbabwe, preliminary results. Hydrobiologia 287: 233-242.

Flores-Crespo J, Velarde FI, Flores-Crespo R and Pelaez CGV. 1992. Variación estacional de Dactylogyrus sp. en dos unidades produtoras de tilapia del estado de Morelos. Tecnica Pecuaria en Mexico 30: 109-118.

ForTes E, HoFFMANN RP AND SCARIOT J. 1998. Lernaea cyprinacea Linnaeus, 1758 (Crustacea, Copepoda) parasitando peixes de água doce da grande Porto Alegre, RS, Brasil. Rev Bras Med Vet 20: 64-65.

Galli P, Crosa G, Bertoglio S, Mariniello L, Ortis M AND D'Amelio S. 2001. Populations of Lamproglena pulchella von Nordmann 1832 (Copepoda: Eudactylinidae) in cyprinid fish in rivers with different pollution levels. J Appl Ichthyol 17: 93-96.

Ghiraldelli L, Martins ML, Jerônimo GT, YAmaSHITA MM AND ADAMANTE WB. 2006a. Ectopara- 
sites communities from Oreochromis niloticus raised in the State of Santa Catarina, Brazil. J Fish Aquat Sci 1: 181-190.

Ghiraldelli L, Martins ML, Yamashita MM AND JERÔNIMO GT. 2006b. Ectoparasites influence on the haematological parameters of Nile tilapia and carp cultured in the State of Santa Catarina, South Brazil. J Fish Aquat Sci 1: 270-276.

Halmetoja A, Valtonen ET And Taskinen J. 1992. Trichodinids (Protozoa) on fish from central finnish lakes of differing water quality. Aqua Fenica 22: 59-70.

KANEKO JJ, YAMADA R, BROCK JA AND NAKAMURA RM. 1988. Infection of tilapia, Oreochromis mossambicus (Trewavas), by a marine monogenean, Neobenedenia melleni (MacCallum, 1927) Yamaguti, 1963 in Kaneohe Bay, Hawaii, USA, and its treatment. J Fish Dis 11: 295300 .

KorolefF F. 1976. Determination of nutrients. In: GRASSHOF K (Ed), Methods of Seawater Analysis. Verlag Chemie Wenheim, Germany, p. 117-181.

KoskivaAra M, Valtonen ET and Prost M. 1991. Seasonal occurrence of gyrodactylid monogeneans on the roach (Rutilus rutilus) and variation between four lakes of differing water quality in Finland. Aqua Fenica 21: 47-55.

KRITSKy DC AND ThatCher VE. 1974. Monogenetic trematodes (Monopisthocotylea: Dactylogyridae) from freshwater fishes of Colombia, South America. J Helminthol 48: 59-66.

KumARi P, KherA S AND GuPTA NK. 1989. On six new species of the genus Lamproglena Nordmann (Copepoda: Eudactylinidae) ectoparasitic on freshwater fishes of India. Res Bull Panjab Univ Sci 40: 9-23.

LEONG TS. 1986. Seasonal occurrence of metazoan parasites of Puntius binotatus in na irrigation canal. Pulau Pinang, Malaysia. J Fish Biol 28: 9-16.

Madsen HCK, Buchmann K and Mellergaard S. 2000. Association between trichodiniasis in eel (Anguilla anguilla) and water quality in recirculating systems. Aquaculture 187: 275-281.

Malta JCO, Gomes ALS, Andrade SMS And VARELLA AMB. 2001. Infestações maciças por acantocéfalos Neoechinorhynchus buttnerae Golvan, 1956, (Eoacanthocephala: Neoechinorhynchidae) em tambaquis jovens, Colossoma macropomum (Cuvier, 1818) cultivados na Amazônia Central. Acta Amazonica 31: 133-143.
Martins ML AND GHiRAldelli L. 2008. Trichodina magna Van As and Basson, 1989 (Ciliophora: Peritrichia) from cultured Nile tilapia in the State of Santa Catarina, Brazil. Braz J Biol 68: 169-172.

Martins ML, Onaka EM, Moraes FR, Bozzo FR, PAIVA AMFC AND GonÇALVES A. 2002. Recent studies on parasitic infections of freshwater raised fish in the State of São Paulo, Brazil. Acta Scientiarum 24: 981-985.

Martins ML, Mouriño JlP, Amaral GV, Vieira FN, Dotta G, Bezerra AJM, Pedrotti FS, Jerônimo GT, Buglione Neto CC And Pereira JR G. 2008. Haematological changes in Nile tilapia experimentally infected with Enterococcus sp. Braz J Biol 68: 631-637.

Marx HM And Avenant-Oldewage A. 1996. Redescription of Lamproglena clariae Fryer, 1956 (Copepoda, Lernaeidae) with notes on its occurrence and distribution. Crustaceana 69: 509-523.

MellergaARd S AND DalsgaARD I. 1987. Disease problems in Danish eel farms. Aquaculture 67: 139-146.

Mendes PP. 1999. Estatística Aplicada a Aqüicultura. Recife: Bagaço, $265 \mathrm{p}$.

Piasecki W, Goodwin AE, EIRAs JC AND NowaK BF. 2004. Importance of copepoda in freshwater fish. Zoological Studies 43: 193-205.

SAGLAM N. 1998. Investigation of Lamproglena pulchella (Nordmann, 1832) on Capoeta trutta and Chondrostoma regium caught in Keban Dam Lake (Elazig, Turkey). J Appl Ichthyol 14: 101-103.

Singhal RN, JeEt S AND DaVIES RW. 1986. The relationships between changes in selected physico-chemical properties of water and the occurrence of fish parasites in Haryana, India. Trop Ecol 27: 1-9.

SKINNER RH. 1982. The interrelation of water quality, gill parasites and gill pathology of some fishes from South Biscayne Bay, Florida. Fish Bull 80: 269-280.

SOUZA FJ, SchapPo CL, TAMASSIA STJ AND BORCHARTI I. 2003. Estudo de competitividade da piscicultura no Vale do Itajaí. Instituto Cepa/SC/Epagri/Acaq, 76 p.

TAVARes-Dias M, Martins ML AND Moraes FR. 2001a. Fauna parasitária de peixes oriundos de "pesque-pague" do município de Franca, São Paulo, Brasil. I. Protozoários. Rev Bras Zool 18: 67-79.

TAVAREs-Dias M, Moraes FR, Martins ML AND KroNKA SN. 2001b. Fauna parasitária de peixes oriundos de "pesque-pague" do município de Franca, São Paulo, Brasil. II. Metazoários. Rev Bras Zool 18: 81-95. 
Thomas S AND HAMEed S. 1984. Description of new species of Lamproglena (Copepoda: Lernaeidae) from Kerala. Indian J Fish 31: 223-227.

UraWA S. 1992. Trichodina truttae Mueller, 1937 (Ciliophora: Peritrichida) on juvenile Chum Salmon (Oncorhynchus keta): pathogenicity and host-parasite interactions. Gyobyo Kenkyu 27: 29-37.

Varella AMB, Peiro SN and Malta JCO. 2003. Monitoramento da parasitofauna de Colossoma macropomum (Cuvier, 1818) (Osteichthyes: Characidae) cultivado em tanque-rede em um lago de várzea na Amazônia Central. XII Simp Bras Aqüic, Goiânia 2: 95-106.
VArgas L, Povh JA, Ribeiro RP AND MOREIRA HLM. 2000. Prevalência de ectoparasitos en tilapia del Nilo (Oreochromis niloticus) de origen tailandesa de Maringá, Paraná. Arq Ciên Vet Zool Unipar 3: 32-37.

YAMBOT AV AND LOPEZ EA. 1996. Gill parasite, Lamproglena monodi Capart, infecting the Nile tilapia, Oreochromis niloticus L., cultured in the Phillippines. Proceedings Third Symp Dis Asian Aquac, 26 Jan to 2 Feb, Bangkok, Thailand, p. 175-177. 